\title{
Prevalence and risk factors of work related stress among residents at Ain Shams University Hospitals
}

Abdel Aziz M Kamal", Sahar M Sabbour", Ihab S Habeel" and Eman A Ghanem*.

*Department of Community, Environmental and Occupational Medicine, Faculty of Medicine, Ain Shams University

\begin{abstract}
Background: Work related stress is an increasingly important occupational problem and a significant cause of economic loss. Objectives: To measure the prevalence and to determine the risk factors of work related stress among residents working in Ain Shams University Hospitals. Subjects and Methods: A crosssectional study was conducted in which the study population consisted of residents working in different departments in the four main Ain Shams University Hospitals. In this study, 488 residents from a total of 557 accepted to participate, their age ranged from 24 to 29 years old (mean $\pm \mathrm{SD}=26.9 \pm 1.3$ years), $49.6 \%$ of them were males and $50.4 \%$ were females. Self- administered questionnaire was used including general health questionnaire-12 items (GHQ) and questionnaire for stress risk factors. Results: $58 \%$ of the residents were stressed, $28.1 \%$ of them scored mild stress and $29.9 \%$ scored severe stress. Regarding stress risk factors, being a female, difficulty in taking vacation, uncomfortable work environment, problems in communication with supervisors and perception of doing work of no value were the most important independent predictors for work related stress by using logistic regression model. Conclusion: Stress is prevalent among residents working at Ain Shams University Hospitals which imply that immediate intervention programs are needed to overcome these problems and to keep residents physically and mentally healthy.
\end{abstract}

\section{Introduction}

Work related stress is an important problem that affects physicians. WHO defines work related stress as the response people may have when presented with work demands and pressures that are not matched to their knowledge and abilities and which challenge their ability to cope $^{(\mathbf{1})}$.

Resident doctors in developing countries encounter additional challenges including shortage of health sector budget, low income and disparities in health care distribution. 
The need to study and work simultaneously make them more susceptible to psychological problems ${ }^{(2)}$. The intense emotional, psychological, and physical demands during residency were aimed to nurture caring, dynamic, and competent medical professionals towards enhancing patient centered care. Despite such noble intentions and goals, these efforts have led to opposite consequences and effects. Work related stress can result in poor morale and motivation, poor communication and decision-making as well as poor relationships with colleagues. It also has financial implications through doctors taking sick leave or ceasing to practice medicine ${ }^{(3)}$.

In Egypt, a study was carried out at Al Mansoura University Hospitals among anesthesiologists who had academic career showed that $69.4 \%$ of them were encountering job stress ${ }^{(4)}$. Another study conducted at Ain Shams University Hospitals showed that $62.3 \%$ of nurses had moderate level of stress ${ }^{(5)}$.

In South Africa, a study carried by Govender et al (2012) showed that $51 \%$ of doctors working at public hospitals were found to be stressed; $27 \%$ of them were highly stressed ${ }^{(6)}$. In India, the overall prevalence of stress among resident doctors working in four medical colleges and associated hospitals of Delhi was $32.8 \%{ }^{(7)}$. In Canada, Edmonds et al (2012) reported that $50 \%$ of healthcare workers working in oncology departments at four major hospital centers in Ontario had high levels of psychological distress ${ }^{(8)}$.

Various stressors have been found to be related to job stress among doctors as demands of work, excessive work load, long duty hours, financial problems, conflict between professional and personal lives, problems with patients and those related to occurrence of death (9).

$\begin{array}{cc}\text { Medical residents } & \text { are } \\ \text { werburdened } & \text { with }\end{array}$ expectations causing negative health effects. It inhibits motivation causing reduced concentration, attention, and impaired cognitive function. These effects predispose residents to medical errors and injuries, substance abuse, and suicide attempts ${ }^{(\mathbf{1 0})}$.

Ain Shams University hospitals include 557 residents working in the different departments in year 2011-2012. These residents face many stressors and inspite the fact that the quality of health care can be extremely influenced by the 
stressed health staff, there is scarce in studies concerning work related stress conducted among Egyptian physicians. So, this study will be beneficial to highlight the problem regarding the magnitude of work related stress and the associated risk factors in order to prevent or reduce it.

\section{Objectives}

1. To measure the prevalence of work related stress among residents working at Ain Shams University hospitals.

2. To determine the risk factors of work related stress among residents at Ain Shams University hospitals.

\section{Subjects and methods}

A cross-sectional study was conducted among residents at Ain Shams University Hospitals in the period from first of April 2013 to end of May 2014. Data obtained from the information center revealed that there were 557 residents at Ain Shams University hospitals in all its departments in 2011-2012. There were 266 residents at internal medicine hospital, 210 residents at EL Demerdash hospital for surgery, 35 residents at gynecology and obstetrics hospital, 33 residents at pediatric hospital and 13 residents at oncology department. A selfadministered questionnaire was completed by the residents. The questionnaire includes:

A) Socio-demographic and job characteristics information.

B) General Health Questionnaire-12 items: it is a validated questionnaire with high sensitivity that has been widely used to screen populations for stress (7). It was decided to use the Likert style for scoring (0-1-2-3). All those who had scored 15 and below were labeled as not stressed, those who had scored above 15 were considered to be in mild stress and those who scored 20 and above were considered to have severe stress ${ }^{(11)}$.

C) Work related stress questionnaire (modified form of $\mathrm{Al}$ Omar, 2003 questionnaire $\left.{ }^{(\mathbf{1 2})}\right)$ : It included statements cited in the literature as stress causes and classified into the following categories: leisure time factors, factors intrinsic to work, work environment and relationships with others at work.

For scaling the responses a fivepoint Likert scale of agreement or disagreement was used. The format of a typical five-level Likert item is: $1=$ strongly disagree, $2=$ disagree, $3=$ neutral, $4=$ agree and $5=$ strongly 
agree. Pilot study was carried out on 10 residents to test the tool to ensure its practicability and applicability. Data were revised, coded and entered to personal computer and analyzed using SPSS version 18. Suitable analysis was done according to the type of data. Ethical committee and administrative approvals were obtained before conducting the study.

\section{Results}

Only 488 of residents have completed the questionnaire with response rate $89.2 \%$. The demographic characteristics of the studied sample showed that their age ranged from 24 to 29 years old, majority of them were single $60.2 \%$ and $50.4 \%$ of them were females. Exploring the job characteristics revealed that $35 \%$ of the residents were juniors, $30.3 \%$ were sub seniors, while $34.6 \%$ were seniors. Residents working at gynecology and obstetrics department were $7.2 \%$ of the studied sample, $6.6 \%$ at pediatric department, $52.9 \%$ at internal medicine department, $30.7 \%$ at surgery department and $2.7 \%$ at oncology department.

Work related stress is prevalent among residents working at Ain
Shams University Hospitals. More than half of the residents $58 \%$ were stressed, $28.1 \%$ of them scored mild stress and $29.9 \%$ of them scored severe stress.

Univariate analysis of the sociodemographic factors revealed that age, marital status, number of children and pregnancy status did not show significant relations with stress, while gender did significantly affect work related stress. Females had significantly higher level of stress than males (table 1). Analysis of the job characteristic factors did not reveal an association between job rank and specialty in relation to stress.

The current study revealed an association between leisure time factors and work related stress where residents who were suffering from short break during work, family problems due to their work and lack of time for practicing hobbies and sports or difficulty in taking vacation were significantly more stressed than those not suffering (table 2).

The current study revealed a significant association between work related stress and the following variables: workload, long working hours, irregularity of schedule of work shift (days and nights), perception of doing job of 
no value, role ambiguity and role conflict (table 3).

Moreover, the current study revealed significant relation between problems with supervisors, colleagues, subordinates, patients and their families and work related stress (table 5). In addition, the current finding revealed that there was a statistically significant relation between uncomfortable environmental work condition and work related (table 4).

Multivariate logistic regression analysis revealed that difficulty in taking vacation, problems in communication with supervisors, perception of doing job of no value, uncomfortable work environment and being a female were the most important independent predictors of work related stress (table 6).

\section{Discussion}

The results of this study show that more than half of the residents $58 \%$ were stressed. Shams and El Masry (2013) reported that $69.4 \%$ of the anesthesiologists who had academic career and working at Mansoura University Hospitals were stressed ${ }^{(4)}$ while Boran et al (2012) showed that $27 \%$ of health care professionals reported high levels of stress ${ }^{(\mathbf{1 3})}$. The higher overall prevalence of stress in the current study could be due to different working environment at the place under study, especially that it is associated with academic demands, high flow of patients and low resources ${ }^{(4)}$.

Female residents had significantly higher level of stress than males. Reasons for this difference should be considered. More serious consequences might occur among females compared with males experiencing the same level of occupational stress. Moreover, female physicians confront more workplace adversity than males in terms of mistrust from the patients, as well as having the dual responsibilities of career and family ${ }^{(14)}$. This finding is consistent with the results of Gramstad et al (2013) which revealed that female physicians experienced higher levels of job stress than males ${ }^{(15)}$. However, male doctors showed more stress than female doctors in a study done in governmental hospitals in India by Baba (2012) (16).

The current study revealed an association between leisure time factors (short break, difficulty in taking vacation, no time for practicing sports and family problems due to work) and work 
related stress among residents (table

2). Several past studies are in agreement with this finding. $\mathrm{El}$ Hussiney (2006) who studied burnout among doctors who have administrative positions at Ain Shams University, found that doctors who had no times for practicing sports or favorite hobbies as well as those who had insufficient vacation (less than two weeks) had significantly higher emotional exhaustion and depersonalization scores (17). Moreover, Ahmad (2010) found a significant association between work-family conflict and stress and burnout among doctors. Workfamily conflict could lead to stress and emotional exhaustion because resources are lost in the process of juggling both work and family roles (18) which could explain the current finding. Moreover, insufficient doctors result in increase their nightshifts, extending working hours and working on weekly vacation and even national legal holidays.

Concerning workload, the present study found a statistically significant association between workload and work related stress as shown in table (3). One explanation that was stated in a previous study by Aslam et al (2013) that is applicable to the current situation is that workload is more in public hospitals as patients' turnover rate is drastic in these hospitals that patients have to wait in emergency departments for longer hours and that causes a lot of pressure for doctors and other staff and act as a source of stress ${ }^{(19)}$.

The current result is supported by the finding of Ahmad (2010) who found that workload is a significant stressor associated with stress and emotional exhaustion ${ }^{(\mathbf{1 8})}$. Moreover, Abdel Hamid (2004) reported that workload was one of the major causes of stress among nurses working in Ain Shams University Hospitals ${ }^{(5)}$.

Regarding long working hours, the current study found a statistically significant association between long working hours and work related (table, 3 ). It could be due to the fact that working long hours requires constantly caring for ill people, facing death of people and knowing that their occupation carries enormous responsibility and that people's lives depend on them (19).

The current result is supported by the finding of El Hussiney (2006) which revealed that total hours worked per day were significantly associated with 
burnout syndrome ${ }^{(17)}$. In contrast, the current result disagrees with the result of Govender et al (2012) who did not find a significant relationship between stress and long working hours. This contradiction in results could be explained by limited sample size and by the differences in working conditions and culture ${ }^{(\mathbf{6})}$.

Concerning work shifts, the current study found that the effect of irregularity of work shifts on work related stress is statistically significant (table 3). It could be explained by the fact that human body clock is used to work at day and sleep at night but when body clock routine is changed anxiety, fatigue, stress and feeling of depression are inevitable mainly due to sleep deprivation. In addition, work shifts disturb the doctors' family and personal life. The present result is consistent with the result of Aslam (2013) which revealed that night shifts and relation with peers have a positive relationship with levels of stress ${ }^{(\mathbf{1 9})}$.

The current study showed that there was a significant relation between stress and perception of doing job of no value (table 3 ). It could be explained by the fact that inability to be involved in decision making pushes the workers to feel that their role is worthless. Another explanation is that in public hospitals, doctors often have to do some non-clinical tasks which could be of no value ${ }^{(20)}$. This agrees with the result of Imtiaz and Ahmad (2010) who reported a significant relation between stress and low acceptance of work done among medical officers working in the main medical organizations in Islamabad ${ }^{(20)}$.

The current finding shows that the residents who were suffering from no clear job description (role ambiguity) are at risk of stress about two and half times than those who were not suffering (table 3 ). It could be due to that uncertainty, inadequate knowledge of employees about their responsibilities, authority, objectives and goals of their organization increase the level of stress among employees and increase the workload ${ }^{(21)}$.

Regarding role conflict, residents who were suffering from opposed views with their supervisors (role conflict) are at risk of stress about three times than those who were not suffering (table 3). Expressing a different opinion may lead to a situation where damage and stress can occur ${ }^{(22)}$. This is in agreement with the 
finding of Karimi et al (2014) who concluded that there was a significant, linear and positive relationship between role overload, role conflict, role ambiguity and occupational stress among nurses (23)

Of the significant factors, there was a relation between problems with supervisors, colleagues and subordinates and work related stress (table 5). It could be due to that ineffective management, supervisors' excessive authority, favouritism and discrimination result in stress ${ }^{(24)}$. Poor relationships with others lead to less trust and support between peers, subordinates, and supervisors which result in stress ${ }^{(12)}$. The current results are supported by the results of El Hussiney (2006) which revealed that doctors who are having good relationships with their colleagues and subordinates had significantly lower degree of emotional exhaustion and depersonalization ${ }^{(\mathbf{1 7})}$. Abdel Hamid (2004) reported that problems with supervisors, patients and their families were the major causes of stress among nurses working in Ain Shams University Hospitals ${ }^{(5)}$.

On the other hand, Menon et al (2007) showed that working relationships were relatively rarely identified as stressors suggesting that colleagues may be an important source of support ${ }^{(9)}$. In addition, Sieminska and Dawid (1997) have identified the buffering effect of social support on stress. They reported that social support for doctors is the most important to return to inner equilibrium ${ }^{(25)}$.

The current study revealed significant relations between problems with patients and their families and work related stress (table 5). It could be explained by the fact of that working with patients who have frequent complaints and discomfort seems to cause excessive workload as providing psychological support to them and/or responding to the their complaints ${ }^{(26)}$. These results are supported by the results of Assibi et al (2013) which revealed that problems with patients and their families are significantly associated with work related stress among nurses ${ }^{(27)}$.

Moreover the current study revealed that there was a statistically significant relation between uncomfortable environmental work condition and work related stress (table 4). Roelofsen (2002) attributed this to a clear association between an individuals' uncomfortable working 
environment and psychological and physical health problems which result in stress ${ }^{(28)}$. This result is in consistent with the result of $\mathrm{Al}$ Dubai et al (2013) which revealed that one of the five most important stressors reported by majority of the Malaysian medical residents was lack of adequate comfortable rest rooms and other facilities for doctors $^{(29)}$.

In multivariable logistic regression analysis, difficulty in taking vacation, problems in communication with supervisors, perception of doing job of no value, uncomfortable work environment and being a female were the most important independent predictors of work related stress (table 6). This analysis showed that residents who were suffering from difficulty in taking vacation, uncomfortable work environment, perceive their job as of no value, have increased the risk of work related stress by about 2.5 folds than those who were not suffering. Also residents who were suffering from problems with their supervisors have increased the risk of work related stress by 2.2 folds than those who were not suffering. In addition, being a female increase the risk of stress by 1.9 folds than being a male.

\section{Conclusion:}

Conclusion drawn from this study is that the degree of work related stress among residents in Ain Shams University Hospitals is considerably high; this stress is mainly related to their work place and caused by a number of workplace stressors identified by them. The most important independent risk factors identified by logistic regression model were: difficulty in taking vacation, problems in communication with supervisors, perception of doing job of no value, uncomfortable work environment and being a female.

\section{References:}

\section{1) World Health Organization (WHO) (2013).} Stress at work place. Available online at: http://www.who.int/occupational_h ealth/topics/stressatwp/en/

2) Deshpande JD, Phalke DB, Kalakoti P, Qutub D and Agrawal V (2013). Stress Levels and Depression amongst Interns and Resident Doctors Working in a Tertiary Care Teaching Hospital in Rural Area. International Journal of Health and Rehabilitation Sciences; 2 (1): 208-220

3) Stebbing $\mathbf{J}$ and Powles $\mathbf{T}$ (2007). Stress in the workplace 
amongst medical professionals. Journal of postgraduate medicine; 53 (2): 83-84

\section{4) Shams $\mathbf{T}$ and El-Masry $R$} (2013). Job Stress and Burnout among Academic Career Anesthesiologists at an Egyptian University Hospital. Sultan Qaboos University Medical Journal; 13(2): 287-295

5) Abdel Hamid MA (2004). Work related stress among staff nurses in Ain Shams University hospitals (MSc thesis). Ain Shams University, Cairo

6) Govender I, Mutunzi E and Okonta HI (2012). Stress among medical doctors working in public hospitals of the Ngaka Modiri Molema district (Mafikeng health region), North West province, South Africa. The South African journal of psychiatry; 18 (2)

7) Saini NK, Agrawal S, Bhasin SK, Bhatia MS and Sharma AK (2010). Prevalence of stress among resident doctors working in Medical Colleges of Delhi. Indian journal of public health; 54(4): 219-23

8) Edmonds C, Lockwood G, Bezjak $A$ and Nyhof-Young J (2012). Alleviating emotional exhaustion in oncology nurses: an evaluation of Wellspringes "Care for the Professional Caregiver Program", J Canc Educ; 27 (1): 2736

9) Menon A and Munalula B (2007). Stress in Doctors: A Pilot Study of the University Teaching Hospital, Lusaka, Zambia. Journal of Psychology in Africa; 17(1): 137-140

10) Issa BA, Yussuf AD, Olanrewaju GT, and Oyewole AO (2009). Stress in residency training as perceived by resident doctors in a Nigerian university teaching hospital. European Journal of Scientific Research; 30 (2): 253 259

11) Rehman S, Kumar R, Siddiqui N, Shahid Z, Syed S and Kadir M (2012). Stress, job satisfaction and work hours in medical and surgical residency programs in private sector teaching hospitals of Karachi, Pakistan. Journal of Pakistan medical association; 62 (10): 1112

12) AL Omar BA (2003). Sources of Work-Stress among Hospital-Staff at the Saudi MOH. JKAU: Econ. \& Adm; 17(1): 3-16

13) Boran A, Shawaheen $M$, Khader Y, Amarin $Z$ and Hill Rice V (2012). Work-related stress among health professionals in northern Jordan. Occup Med (Lond) ; 62(2):145-7 
14) Roxburgh $S$ (1996). Gender differences in work and well-being: effects of exposure and vulnerability. See comment in PubMed Commons belowJ Health Soc Behav; 37(3): 265-77

15) Gramstad TO, Gjestad $R$ and Haver $B$ (2013). Personality traits predict job stress, depression and anxiety among junior physicians. BMC Medical Education; 13:150

16) Baba I (2012). Workplace stress among doctors in government hospitals: An empirical study. International Journal of Multidisciplinary Research; 2(5)

17) EL Hussiney DM (2006). Burnout Syndrome among Professors with Administrative Duties in Ain Shams University (MSc thesis). Ain Shams University, Cairo

18) Ahmad A (2010).WorkFamily Conflict among Junior Physicians: Its Mediating Role in the Relationship between Role Overload and Emotional Exhaustion. Journal of Social Sciences; 6 (2): 265-271

19) Aslam HD, Mansoor $\mathbf{N}$ and Suleman Q (2013). Analysis of Level of Stress among Doctors in Public and Private Hospitals of Pakistan; 3(2)

20) Couper I (2006). How to cope with stress and avoid burnout. In: Mash B, Blitz-Lindeque J, eds. South African Family Practice
Manual. 2nd ed. Pretoria: Van Schaik :379-380

21) Imtiaz $S$ and Ahmad $S$ (2010). The Impact of Stress on Employee Productivity, Performance and Turn over: an important managerial issue (thesis). Department of management sciences, Institute of Information Technology, Pakistan

22) Idris MK (2011). Over time effects of role stress on psychological strain among Malaysian public university academics. International Journal of Business and Social Science; 2(9): $154-161$

23) Saltman DC, O'Dea NA and Kidd MR (2006). Conflict management: a primer for doctors in training. Postgrad Med J; 82(963): 9-12

24) Karimi R, Omar ZB, Alipour F and Karimi Z (2014). The influence of role overload, role conflict and role ambiguity on occupational stress among nurses in selected Iranian Hospitals. International Journal of Asian Social Science; 4(1):34 - 40

25) Sadri G and Marcoulides GA (1997). An examination of academic and occupational stress in the USA. International Journal of Educational Management; 11(1), $32-43$ 
26) Sieminska MJ and Dawid

G (1997). Professional stress of physicians. Przeglad Lekarski; 54 (7-8): 529-532

27) Assibi AR, Atindanbila S, Portia MP and Abepuoring $P$ (2013). The causes of stress and job satisfaction among nurses at Ridge and Pantang Hospitals in Ghana. International Journal of Asian Social Science; 3(3):762-771

28) Roelofsen $P$ (2002). The impact of office environments on employee performance: The design of the workplace as a strategy for productivity enhancement. Journal of Facilities Management; 1 (3): $247-264$

\section{9) Al-Dubai SA, Ganasegeran} $\mathrm{K}$, Perianayagam $\mathrm{W}$ and Rampal KG (2013). Emotional Burnout, Perceived Sources of Job Stress, Professional Fulfillment, and Engagement among Medical Residents in Malaysia. The Scientific World Journal; 2013: Article ID 137620, 9 pages 
Table (1): Relation between socio-demographic data and work related stress among the study group

\begin{tabular}{|c|c|c|c|c|c|c|}
\hline Variables & $\begin{array}{c}\text { Stressed } \\
\mathbf{n}=\mathbf{2 8 3} \\
\mathbf{N}(\%)\end{array}$ & $\begin{array}{c}\text { Not } \\
\text { stressed } \\
\mathbf{n}=\mathbf{2 0 5} \\
\mathbf{N}(\%)\end{array}$ & $\mathbf{X}^{2}$ & $\mathbf{P}$ & $\begin{array}{l}\text { Odds } \\
\text { ratio }\end{array}$ & $\begin{array}{c}95 \% \\
\text { CI }\end{array}$ \\
\hline $\begin{array}{l}\text { Gender } \\
\text { Females } \\
\text { Males }\end{array}$ & $\begin{array}{l}161(65.4) \\
122(50.4)\end{array}$ & $\begin{array}{c}85(34.6) \\
120(49.6)\end{array}$ & 11.3 & 0.001 & 1.9 & 1.3-2.7 \\
\hline $\begin{array}{l}\text { Age } \\
24-26 \\
27-29 \\
\end{array}$ & $\begin{array}{l}109(59.2) \\
173(57.5)\end{array}$ & $\begin{array}{c}75(40.8) \\
128(42.5)\end{array}$ & 0.1 & 0.7 & 1.1 & $0.7-1.6$ \\
\hline $\begin{array}{l}\text { Marital status } \\
\text { Married } \\
\text { Single } \\
\text { Divorced }\end{array}$ & $\begin{array}{c}108(57.1) \\
172(58.5) \\
3(60)\end{array}$ & $\begin{array}{c}81(42.9) \\
122(41.5) \\
2(40)\end{array}$ & $0.2 *$ & 0.9 & $\begin{array}{l}\text { Ref } \\
1.1 \\
1.1\end{array}$ & $\begin{array}{c}-- \\
0.7-1.5 \\
0.2-6.9\end{array}$ \\
\hline $\begin{array}{l}\text { Pregnancy } \\
\text { Pregnant } \\
\text { Not pregnant }\end{array}$ & $\begin{array}{l}20(62.5) \\
57(67.1)\end{array}$ & $\begin{array}{l}12(37.5) \\
28(32.9)\end{array}$ & 0.2 & 0.6 & 0.8 & $0.4-1.9$ \\
\hline $\begin{array}{l}\text { Number } \\
\text { children } \\
\text { No children } \\
1 \text { child } \\
2 \text { children }\end{array}$ & $\begin{array}{c}220(57.1) \\
48(60) \\
15(65.2)\end{array}$ & $\begin{array}{c}165(43) \\
32(39.5) \\
8(34.8)\end{array}$ & 0.7 & 0.7 & $\begin{array}{l}\text { Ref } \\
1.1 \\
1.4\end{array}$ & $\begin{array}{c}-- \\
0.7-1.8 \\
0.6-3.4\end{array}$ \\
\hline
\end{tabular}

*Fisher exact test. $\quad$ Ref $=$ reference group 
Table (2): Relation between leisure time and work related stress among study group

\begin{tabular}{|c|c|c|c|c|c|c|}
\hline Variables & $\begin{array}{c}\text { Stressed } \\
\mathbf{n}=\mathbf{2 8 3} \\
\mathbf{N}(\%)\end{array}$ & $\begin{array}{c}\text { Not } \\
\text { stressed } \\
\mathbf{n}=\mathbf{2 0 5} \\
\mathbf{N}(\%)\end{array}$ & $\mathbf{X}^{2}$ & $\mathbf{P}$ & $\begin{array}{l}\text { Odds } \\
\text { ratio }\end{array}$ & $\begin{array}{c}95 \% \\
\text { CI }\end{array}$ \\
\hline $\begin{array}{l}\text { Suffering from family } \\
\text { problems due to work } \\
\text { Disagree } \\
\text { Neutral } \\
\text { Agree }\end{array}$ & $\begin{array}{l}40(32.3) \\
71(56.8) \\
172(72)\end{array}$ & $\begin{array}{c}84(67.7) \\
54(43.2) \\
67(28)\end{array}$ & 52.9 & $<0.001$ & $\begin{array}{l}\text { Ref } \\
2.8 \\
5.4\end{array}$ & $\begin{array}{c}-- \\
1.6-4.6 \\
3.4-8.6 \\
\end{array}$ \\
\hline $\begin{array}{l}\text { In ability to practice } \\
\text { hobbies or sports due } \\
\text { to work } \\
\text { Disagree } \\
\text { Neutral } \\
\text { Agree }\end{array}$ & $\begin{array}{c}9(28.1) \\
27(42.2) \\
247(63)\end{array}$ & $\begin{array}{c}23(71.9) \\
37(57.8) \\
145(37)\end{array}$ & 22.3 & $<0.001$ & $\begin{array}{l}\text { Ref } \\
1.9 \\
4.4\end{array}$ & $\begin{array}{c}-- \\
0.7-4.7 \\
2-9.7 \\
\end{array}$ \\
\hline $\begin{array}{l}\text { Difficulty in taking } \\
\text { vacation } \\
\text { Disagree } \\
\text { Neutral } \\
\text { Agree } \\
\end{array}$ & $\begin{array}{c}26(59.1) \\
32(37.6) \\
225(62.7) \\
\end{array}$ & $\begin{array}{c}18(40.9) \\
53(62.4) \\
134(37.3) \\
\end{array}$ & 17.8 & $<0.001$ & $\begin{array}{l}2.4 \\
\text { Ref } \\
2.8 \\
\end{array}$ & $\begin{array}{c}1.1-5 \\
-- \\
1.7-4.5 \\
\end{array}$ \\
\hline $\begin{array}{l}\text { Breaks period during } \\
\text { work are short } \\
\text { Disagree } \\
\text { Neutral } \\
\text { Agree }\end{array}$ & $\begin{array}{c}30(51.7) \\
56(45.9) \\
197(64)\end{array}$ & $\begin{array}{c}28(48.3) \\
66(54.1) \\
111(36)\end{array}$ & 12.8 & 0.002 & $\begin{array}{l}1.3 \\
\text { Ref } \\
2.1\end{array}$ & $\begin{array}{c}0.7-2.4 \\
-- \\
1.4-3.2\end{array}$ \\
\hline
\end{tabular}


Table (3): Relation between factors intrinsic to work and work related stress among study group

\begin{tabular}{|c|c|c|c|c|c|c|}
\hline Variables & $\begin{array}{c}\text { Stressed } \\
\mathbf{n}=\mathbf{2 8 3} \\
\mathbf{N}(\%)\end{array}$ & $\begin{array}{c}\text { Not } \\
\text { stressed } \\
\mathbf{n}=\mathbf{2 0 5} \\
\mathbf{N}(\%)\end{array}$ & $X^{2}$ & $\mathbf{P}$ & $\begin{array}{c}\text { Odds } \\
\text { ratio }\end{array}$ & $\begin{array}{c}95 \% \\
\text { CI }\end{array}$ \\
\hline $\begin{array}{l}\text { Perception of } \\
\text { doing work of no } \\
\text { value } \\
\text { Disagree } \\
\text { Neutral } \\
\text { Agree } \\
\end{array}$ & $\begin{array}{l}126(46.7) \\
79(68.1) \\
78(76.5) \\
\end{array}$ & $\begin{array}{l}144(53.3) \\
37(31.9) \\
24(23.5) \\
\end{array}$ & 33.4 & $<0.001$ & $\begin{array}{l}\text { Ref } \\
2.4 \\
3.7 \\
\end{array}$ & $\begin{array}{c}-- \\
1.5-3.9 \\
2.2-6.2 \\
\end{array}$ \\
\hline $\begin{array}{l}\text { High work load } \\
\text { Disagree } \\
\text { Neutral } \\
\text { Agree }\end{array}$ & $\begin{array}{l}47(44.3) \\
94(54.3) \\
142(67.9) \\
\end{array}$ & $\begin{array}{l}59(55.7) \\
79(45.7) \\
67(32.1) \\
\end{array}$ & 17.6 & $<0.001$ & $\begin{array}{l}\text { Ref } \\
1.5 \\
2.7 \\
\end{array}$ & $\begin{array}{c}-- \\
0.9-2.4 \\
1.6-4.3 \\
\end{array}$ \\
\hline $\begin{array}{l}\text { Long working } \\
\text { hours } \\
\text { Disagree } \\
\text { Neutral } \\
\text { Agree }\end{array}$ & $\begin{array}{c}31(48.4) \\
54(47) \\
198(64.1)\end{array}$ & $\begin{array}{c}33(51.6) \\
61(53) \\
111(35.9)\end{array}$ & 12.8 & 0.002 & $\begin{array}{c}1.1 \\
\text { Ref } \\
2\end{array}$ & $\begin{array}{c}0.6-2 \\
-- \\
1.3-3.1\end{array}$ \\
\hline $\begin{array}{ll}\begin{array}{l}\text { Irregularity } \\
\text { schedule of }\end{array} & \begin{array}{r}\text { of } \\
\text { work }\end{array} \\
\text { shifts } & \\
\text { Disagree } & \\
\text { Neutral } & \\
\text { Agree } & \\
\end{array}$ & $\begin{array}{c}42(45.2) \\
69(54.3) \\
172(64.2)\end{array}$ & $\begin{array}{l}51(54.8) \\
58(45.7) \\
96(35.8)\end{array}$ & 11.2 & 0.004 & $\begin{array}{l}\text { Ref } \\
1.4 \\
2.2\end{array}$ & $\begin{array}{c}-- \\
0.8-2.5 \\
1.3-3.5 \\
\end{array}$ \\
\hline $\begin{array}{l}\text { Absence of job } \\
\text { description } \\
\text { Disagree } \\
\text { Neutral } \\
\text { Agree }\end{array}$ & $\begin{array}{c}36(42.9) \\
56(48.7) \\
191(66.1)\end{array}$ & $\begin{array}{l}48(57.1) \\
59(51.3) \\
98(33.9)\end{array}$ & 19.8 & $<0.001$ & $\begin{array}{l}\text { Ref } \\
1.3 \\
2.6\end{array}$ & $\begin{array}{c}-- \\
0.7-2.2 \\
1.6-4.3\end{array}$ \\
\hline $\begin{array}{lr}\begin{array}{l}\text { Suffering } \\
\text { contradiction } \\
\text { opinions }\end{array} & \begin{array}{r}\text { from } \\
\text { of } \\
\text { with }\end{array} \\
\text { supervisors } & \\
\text { Disagree } & \\
\text { Neutral } & \\
\text { Agree } & \\
\end{array}$ & $\begin{array}{l}36(40.4) \\
117(56.5) \\
130(67.7) \\
\end{array}$ & $\begin{array}{l}53(59.6) \\
90(43.5) \\
62(32.3) \\
\end{array}$ & 18.9 & $<0.001$ & $\begin{array}{l}\text { Ref } \\
1.9 \\
3.1 \\
\end{array}$ & $\begin{array}{c}-- \\
1.2-3.2 \\
1.8-5.2 \\
\end{array}$ \\
\hline
\end{tabular}


Table (4): Relation between work environment and work related stress among study group

\begin{tabular}{|l|c|c|c|c|c|c|}
\hline Variables & $\begin{array}{c}\text { Stressed } \\
\mathbf{n = 2 8 3} \\
\mathbf{N}(\mathbf{\%})\end{array}$ & $\begin{array}{c}\text { Not } \\
\text { stressed } \\
\mathbf{n = 2 0 5} \\
\mathbf{N}(\mathbf{\%})\end{array}$ & $\mathbf{X}^{\mathbf{2}}$ & $\mathbf{P}$ & $\begin{array}{c}\text { Odds } \\
\text { ratio }\end{array}$ & $\begin{array}{c}\mathbf{9 5 \%} \\
\mathbf{C I}\end{array}$ \\
\hline $\begin{array}{l}\text { Uncomfortable work } \\
\text { environment (noise, } \\
\text { heat...) }\end{array}$ & & & & & & \\
Disagree & $27(40.9)$ & $39(59.1)$ & & & Ref & - \\
Neutral & $55(50.9)$ & $53(49.1)$ & $\mathbf{1 4 . 8}$ & $\mathbf{0 . 0 0 1}$ & 1.5 & $0.8-2.8$ \\
Agree & $201(64)$ & $113(36)$ & & & 2.6 & $1.5-4.4$ \\
\hline Exposure to health & & & & & & \\
hazards and accidents & $13(54.2)$ & $11(45.8)$ & & & 1.2 & $0.5-3.1$ \\
Disagree & $43(48.9)$ & $45(51.1)$ & 0.4 & 0.1 & Ref & -- \\
Neutral & $227(60.4)$ & $149(39.6)$ & & & 1.6 & $1-2.5$ \\
Agree & & & & & \\
\hline
\end{tabular}


Table (5): Relation between communication with others and work related stress among study group

\begin{tabular}{|c|c|c|c|c|c|c|}
\hline Variables & $\begin{array}{c}\text { Stressed } \\
\mathbf{n}=\mathbf{2 8 3} \\
\mathbf{N}(\%) \\
\end{array}$ & $\begin{array}{c}\text { Not } \\
\text { stressed } \\
\mathbf{n}=\mathbf{2 0 5} \\
\mathbf{N}(\%) \\
\end{array}$ & $X^{2}$ & $\mathbf{P}$ & $\begin{array}{l}\text { Odds } \\
\text { ratio }\end{array}$ & $\begin{array}{c}95 \% \\
\text { CI }\end{array}$ \\
\hline $\begin{array}{l}\text { Suffering from } \\
\text { problems with } \\
\text { supervisors } \\
\text { Disagree } \\
\text { Neutral } \\
\text { Agree }\end{array}$ & $\begin{array}{c}58(38.9) \\
43(58.1) \\
182(68.7)\end{array}$ & $\begin{array}{l}91(61.1) \\
31(41.9) \\
83(31.3)\end{array}$ & 34.7 & $<0.001$ & $\begin{array}{l}\text { Ref } \\
2.2 \\
3.4\end{array}$ & $\begin{array}{c}-- \\
1.2-3.8 \\
2.3-5.2 \\
\end{array}$ \\
\hline $\begin{array}{l}\text { Suffering from } \\
\text { problems with } \\
\text { subordinates } \\
\text { Disagree } \\
\text { Neutral } \\
\text { Agree } \\
\end{array}$ & $\begin{array}{c}136(50.9) \\
58(70.7) \\
89(64) \\
\end{array}$ & $\begin{array}{c}131(49.1) \\
24(29.3) \\
50(36) \\
\end{array}$ & 13 & 0.002 & $\begin{array}{l}\text { Ref } \\
2.3 \\
1.7 \\
\end{array}$ & $\begin{array}{c}-- \\
1.4-4 \\
1.1-2.6 \\
\end{array}$ \\
\hline $\begin{array}{l}\text { Suffering from } \\
\text { problems with } \\
\text { colleagues } \\
\text { Disagree } \\
\text { Neutral } \\
\text { Agree } \\
\end{array}$ & $\begin{array}{c}138(51.9) \\
55(64.7) \\
90(65.7) \\
\end{array}$ & $\begin{array}{c}128(48.1) \\
30(35.3) \\
47(34.3)\end{array}$ & 9 & 0.01 & $\begin{array}{l}\text { Ref } \\
1.7 \\
1.8 \\
\end{array}$ & $\begin{array}{c}-- \\
1-2.8 \\
1.2-2.7 \\
\end{array}$ \\
\hline $\begin{array}{l}\text { Suffering from } \\
\text { problems in } \\
\text { communication with } \\
\text { patients } \\
\text { Disagree } \\
\text { Neutral } \\
\text { Agree }\end{array}$ & $\begin{array}{c}101(46.3) \\
55(75.3) \\
127(64.5)\end{array}$ & $\begin{array}{l}117(53.7) \\
18(24.7) \\
70(35.5)\end{array}$ & 24.6 & $<0.001$ & $\begin{array}{l}\text { Ref } \\
3.5 \\
2.1 \\
\end{array}$ & $\begin{array}{c}-- \\
2-6.4 \\
1.4-3.1 \\
\end{array}$ \\
\hline $\begin{array}{l}\text { Suffering from } \\
\text { problems with in } \\
\text { communication with } \\
\text { patients' family } \\
\text { Disagree } \\
\text { Neutral } \\
\text { Agree }\end{array}$ & $\begin{array}{c}88(48.9) \\
52(68.4) \\
143(61.6) \\
\end{array}$ & $\begin{array}{l}92(51.1) \\
24(31.6) \\
89(38.4)\end{array}$ & 10.8 & 0.005 & $\begin{array}{l}\text { Ref } \\
2.3 \\
1.7 \\
\end{array}$ & $\begin{array}{c}-- \\
1.3-4 \\
1.1-2.5 \\
\end{array}$ \\
\hline
\end{tabular}


Table (6): Multivariate logistic regression analysis for the most important independent predictors of work related stress

\begin{tabular}{|l|c|c|c|c|c|}
\hline & \multirow{2}{*}{ Independent predictors } & $\mathbf{P}$ & $\begin{array}{c}\text { Odds } \\
\text { ratio }\end{array}$ & $\begin{array}{c}\text { Lower } \\
\text { limit }\end{array}$ & $\begin{array}{c}\text { Upper } \\
\text { limit }\end{array}$ \\
\hline Perception of doing work of no value & 0.96 & $\mathbf{0 . 0 0 1}$ & 2.6 & 1.5 & 4.7 \\
\hline $\begin{array}{l}\text { Uncomfortable working environment } \\
\text { (noise, heat...) }\end{array}$ & 0.908 & $\mathbf{0 . 0 0 9}$ & 2.5 & 1.3 & 4.9 \\
\hline Difficulty in taking vacation & 0.888 & $\mathbf{0 . 0 0 1}$ & 2.4 & 1.4 & 4.2 \\
\hline Suffering from problems with supervisors & 0.801 & $\mathbf{0 . 0 0 1}$ & 2.2 & 1.4 & 3.6 \\
\hline Gender (female) & 0.661 & $\mathbf{0 . 0 0 2}$ & 1.9 & 1.3 & 2.9 \\
\hline $\begin{array}{l}\text { Suffering from problems in } \\
\text { communication with patients }\end{array}$ & 0.428 & 0.07 & 1.5 & 1 & 2.4 \\
\hline Inability to take decision & 0.298 & 0.4 & 1.3 & 0.7 & 2.5 \\
\hline
\end{tabular}

